\title{
Reasons for migrating to Ho Chi Minh City
}

\author{
Nguyen Minh $\mathrm{Ha}^{1}{ }^{*}$, Vo Phuoc Tai ${ }^{2}$, Nguyen Quang Thai ${ }^{3}$ \\ ${ }^{1}$ Ho Chi Minh City Open University, Vietnam \\ ${ }^{2}$ Viet Long Company, Vietnam \\ ${ }^{3}$ Ho Chi Minh City Urban Upgrading Investment, Vietnam \\ *Corresponding author: ha.nm@ou.edu.vn
}

\begin{tabular}{ll}
\hline \multicolumn{1}{c}{ ARTICLE INFO } & \multicolumn{1}{c}{ ABSTRACT } \\
$\begin{array}{l}\text { DOI:10.46223/HCMCOUJS. } \\
\text { econ.en.9.2.154.2019 }\end{array}$ & $\begin{array}{c}\text { During the last } 20 \text { years, Vietnam has had a prompt } \\
\text { economic development, the people have the trend for emigrating } \\
\text { from the rural to urban areas, industrial zones and the trading- } \\
\text { service center where it is essential for labor needs to serve for the } \\
\text { industrial and service development in order to look for the better } \\
\text { jobs. The wave of emigrants have not only contributed to an } \\
\text { increase in population in Ho Chi Minh City (HCMC) and other } \\
\text { urban centers in Vietnam but also augmented pressure in the }\end{array}$ \\
$\begin{array}{l}\text { infrastructure system and the issues of social life. } \\
\text { Received: April } 22^{\text {th }}, 2019\end{array}$ & $\begin{array}{l}\text { With the method of Exploratory Factor Analysis (EFA), this } \\
\text { Accepted: May } 31^{\text {st }}, 2019\end{array}$ \\
$\begin{array}{l}\text { research had indicated the main factors impacting on making a } \\
\text { decision for migration to the Ho Chi Minh City, by the collected } \\
\text { data directly from 277 surveyed forms of immigrants to HCMC. } \\
\text { There are } 6 \text { decisive factors including: (1) HCMC's politics and } \\
\text { policies; (2) the family situation and the embroilment of the } \\
\text { friends and fellow-countrymen; (3) better quality needs of life } \\
\text { and individual aspirations; (4) the job opportunities and } \\
\text { occupational development conditions; (5) the job demands with } \\
\text { stable incomes; and (6) the marriage and living with relatives. }\end{array}$ \\
$\begin{array}{l}\text { Keywords: } \\
\text { emigration, Ho Chi Minh } \\
\text { City, immigration }\end{array}$
\end{tabular}

\section{Introduction}

According to the 1999 Vietnamese population and housing census, the rural immigration to an urban area contributed an increase in one-third of the urban population during the 1994-1999 period and in over a half of the HCMC population (Central Population Housing Census Steering Committee, 2010). In addition, pursuant to the Vietnam emigration survey of General Statistics Office (2004) stated that almost emigrants in the 15-25 age groups have moved to the big city directly, and, the men outnumber women in ratio of emigration. Furthermore, the socio-economic difference and differential incomes from the rural job to the urban one lead to the disadvantageous effect on inhabitants and push them to leave out. Concurrently, the urban and big city's development orientation for the educational and professional 
opportunities and the improvement of incomes have created a popular attraction for the rural people moving to urban areas to earn a living, study, and work. Results of the 2009 Vietnam Population and Housing Census proved that emigrants among provinces increased in the relative and absolute numbers, particularly from 1.3 million in 1989 to 2 million in 1999 and 3.4 million in 2009 (Central Population Housing Census Steering Committee, 2010). The situation of emigration in the last decade accelerated the previous one correlatively from $2.5 \%$ in 1989 up to $2.9 \%$ in 1999 and $4.3 \%$ in 2009. Results of the 2009 Vietnam Population and Housing Census proved that Hai Phong and Da Nang Provinces have an increase in the immigrant population with the respective number of $-23,872$ and 63,097 people while the number of Ha Noi and Binh Duong immigrants was 292,426 and 466,070 respectively (Central Population Housing Census Steering Committee, 2010). HCMC had the highest number of immigrants reaching one of 905,331. In the meanwhile, according to the results of the 2014 Intercensal Population and Housing Survey, the national population as of April 1, 2014, was 90,943 thousand people, increasing 4,646 thousand people. And the total population of April 1, 2014, compared to April 1, 2009, saw an increase of 3.45 percent in the urban population (Intercensal Population and Housing Survey, 2014).

Compared with the previous time, labor emigration as a whole made an increase in population and economic growth in the HCMC area. However, under the general angles, the rural emigrant process to urban immigration is growing and shall be a pressure to the infrastructure system, housing issues, education, health care, electricity, water, hygiene, security, and traffic. For these reasons, the target of research aims to define the main factors impacting on making a decision to choose HCMC as an urban area where the labourers migrate to work and earn a living. Since then there will be a suitable policy to reduce the negative effects brought about by the social phenomenon as well as an appropriate implementation one such as managing and supporting jobs to the immigrants.

The article consists of the introduction as the first part, the emigrant theory, and the research model as the second one, the research method as the third one, analytic results as the fourth one before giving a conclusion and the policy suggestions.

\section{Literature reviews and the research model}

\subsection{Emigrant concept}

Pursuant to the General Office for Population and the United Nations Population Fund (2011), the emigration is a human's movement upon the territory with the fixed temporal and spatial restriction, enclosed with the resident change.

The emigrant features are as follows: Firstly, human beings shall move out from a certain place to another with a fixed distance. The departure place (emigration) and the destination place (immigration) must be defined; maybe it is a territory area or an administrative unit. Two points' distance is an emigrant length. Secondly, the departure place (emigration) is a regular residence stipulated upon the household registration form or the personnel registration verified by the authorized administrative management, and the destination is a new residence. The resident characteristic is a necessary condition to define the emigration. Thirdly, how long 
the period of the emigrants stayed at a new residence is an important feature to determine for that movement. The period of staying may be a number of years or a number of months, depending on the goal.

\subsection{Emigrant theories}

Dual sector model: According to Lewis (1954), the redundant labor phenomenon forms the area for traditional production of agriculture (specific to rural) transferred into the modern industrial production (specific to urban) in the industrialized process. The putative model that economics exists only in two areas: the traditional production of agriculture and modern production. Traditional agriculture is handicraft labor commonly in which low productivity leads to a low salary. By contrast, modern industrial productions have high marginal productivity with higher salaries than the area of agricultural economics and need an increase in labor. It has resulted in the appearance of labor movements from the area of traditional agricultural production to the modern industrial ones in the urban areas.

Expected income model: According to Harris and Todaro (1970), unlike Lewis' model (1954) explaining the emigrant origin based on the "redundant labor" purpose in rural areas Harris-Todaro's model illustrates the rural migrant laborers' decision to urban areas based on the difference between the rural and urban expected income. This model explained the existent cause for jobless situation in the developing countries' urban areas, and why people have moved to the city although the jobless issues have been existing insolvably. To resolve these issues, Harris-Todaro model admitted the informal sector's existence. The sector consists of activities that are not absolutely illegal, but the society doesn't admit them officially and most of the activities are not registered to the state (e.g., the labor for family, motorbike taxi, hawker, sharpeners for knives and scissors, food and drink service on sidewalk, picking up bottles, shoe shinning whoredom? etc.).

Lee's push-pull theory: According to Lee's theory (1966), the emigrant influence has both negative and positive sides of departure and destination. The emigrants often expect to reap the added value when moving to any place. The rural emigration to the expected area (city areas) has a problem in both places. It consists of family pressure, moving costs, lack of business capital, illiteracy, state obligations, and languages. Lee also affirms that the city is an advantage for some people, but the disadvantage for other ones.

\subsection{Factors influencing emigrants}

\subsubsection{Economic factors}

Most previous studies stated that the emigration started from issues in relation to the economic factors. Specifically, in developing countries, the main reason causing people to migrate to dynamic economic areas with more working chances is incomes from the low agricultural economic activities and redundant labors. In addition, there is a quick increase in the rural population; simultaneously, there is a decrease in the percentage of agricultural land ownership, which results in an increase in poor family households and in migrant people. The studies also illustrated that most people have decided to move to the city-urban areas where they can get better jobs. The development industry also makes to appear the migrant streams. 
Therefore, the labor demand of plants has increased and appears the rural emigrant trend to urban.

According to the basis of Harris and Todaro (1970), Ranis and Fei (1961), and Lewis macroeconomic theory (1954), the international emigration is occurred by the geography difference between the labor demand and supply. There are some countries with high labor surplus in line with low incomes of the labor market and for other countries with low labor surplus in line with high incomes of the labor market. Thence to force the difference in incomes made the state in which employees from nations with low salaries move to nations with a high salary. According to the macroeconomic theory for individual options (Sjaastad, 1962; Todaro, 1969, 1976, 1989; Todaro \& Maruszko, 1987), laborers make a decisive move due to the cost calculation in order to get an expected benefit as money. However, to get a high salary they must expense a fixed cost, including preparing tools for moving, living costs while moving and looking for job, studying language and new culture, and adapting themselves to new labor surroundings, and other costs influencing on psychology such as getting rid of old relationship and building new relationship.

Besides chance factors for jobs and incomes, the difference between the salary of the rural and urban areas is also a factor to emigrate to developing countries. The concept stated that individuals don't make an emigrant decision that it started from their family in which everybody not only maximizes their incomes but also minimizes risks and overcomes restriction related to the market's failures such as capital market; agricultural goods transaction; cereals; agricultural insurance; jobless insurance for key laborers (Stark, 1984; Stark, 1991; Stark \& Levhari, 1982; Taylor, 1986).

The economic factors that made people emigrate are classified in Push-Pull factors. In other words, emigrants fall down a forced situation looking for a moving opportunity and simultaneously they are influenced by the attraction of good Promised Land. The Push force consists of factors with many different reasons compelling people getting rid of their home and moving to a new place. The cause can start from reasons as low labor productivity, jobless, poor living condition, lack of job and economic development opportunity, exhausted natural resources, drought, and natural calamity, etc. That is the reason for pushing people looking for a place where it is a better living condition. Besides, it is difficult to access the capital financed form for production in agricultural economic areas and the support policy for the local job, also contributing to increase the migration. The Pull force consists of factors pulling labors looking for a certain land area, for example, a place with opportunity for good working, advancement condition in the profession, a more attractive salary rate, better working conditions, and more convenience, etc.

\subsubsection{Demographic factor}

Age: In Asian nations as a typical Thailand, according to Plymas (1999), Suwanlee (1974), almost the emigrant laborers were very young people around the age of 19-20. The above results for the emigrant situation also take place in other developing nations such as Kenya, Nigeria, India, Korea, and the Philippines with the same as Thailand's economic structure (Todaro, 1976). It is also explained that young emigrants always have a lot of ambition 
and expectation of incomes from jobs in urban areas. Furthermore, young people like to change and find new things and do not to be bound. The age also influences on choosing the emigrant place.

Sex: In Africa and Asia, the emigration was done by more men than by women; however, in the recent period, there has been a migrant sign done by more women than by men. In some Asian nations such as India, Korea, and the Philippine, the migration to the city was done more by women than the other gender. However, the migration to rural areas was done by more men than women (Yap, 1977). In Vietnam, the emigrant's demographic feature shows around $60 \%$ of emigrants were males and $66 \%$ for females aged 15-29 and most of them didn't get married yet (census and housing, 1999). The results were similar in the middle period of 2004 in HCMC, specifically, the women's migrant volume gets more and more increasing.

Emigrant's educational level: In Thailand, for education, most emigrants only graduate in the primary school and the rural migrants to the urban areas have lower educational levels than those living in the urban areas (Mowat, 1977; Yap, 1977). The higher people had the educational level, the further they moved with the aim of looking for better economic chances. In addition, most of those having a better educational level shall have the chance for migrating many times and choosing good jobs easily compared with those only moving once (Plymas, 1999).

Marital status: the marriage between husband and wife in the urban areas is also the reason for making people carry out their migration. Typically, in Thailand northeastern areas, according to a research of Prutipinyo (2003) and of Suthum Nanthamongkongchai (1999), most emigrants were single; however, due to the marital status, emigrants shall migrate from the rural to the rural or the urban to the urban, and the rural emigrants to rural will get married more easily than those from the urban to the urban.

Family dependants: In Thailand, according to the study of Ratchanee Kunopakarn (1999), a family with an average number of five people shall have two bread-winners. Especially, the married women must feed their children and other members in the family, thus they think that the labor migrant issues help to send money to their home.

Family household scale: According to Vorakitwat (2001) stated that the possessive family's farmland didn't bring about food and food products for all their family. It shall appear that the labor migrant situation helps to increase additional incomes for their family, and it was also similar to the study results of de Jong and Ferguson-Hessler (1996) in which families with crowded siblings shall be a factor pushing one of them moving to live away from their country.

\subsubsection{Social-cultural-Life quality factors}

Social-cultural factors also play an important role that influences on the people's migrant decision. It can be explained that it is due to nations' typical traditions such as India, China, and Vietnam, etc. However, the migrant type is not profitable in economics. In addition, religious freedom is also an important factor influencing the migrant process, the people have the migrant trend to a community where has strong development in their religion. 
For the young generation nowadays, sometimes they come into conflict with their family and are under the influence of modern thinking, films, the conception of the advanced lifestyle, and simultaneously attracted by comforts and technological science, etc. Since then they desire to access modern physical facilities; all have made the independent finding needs and freedom that they get easily when implementing the migration and moving to the modern and big city (Kainth, 2010). Besides, because of starting from many reasons as the housingland confliction in family and discrimination in all levels of society, the people made a decision to migrate (Kainth, 2010).

Demands for water and power system, convenient traffic and road systems, a safe living environment, mainly good children's educational conditions shall be a cause luring emigrants to the urban areas (Q. Nguyen, 1996).

The migrant phenomenon is more and more popular in the community and makes to change the value, cultural knowledge and an increase in migrant ability in the future. For experienced emigrants, the industrial economic change created migrant motive and desire (Piore, 1979). At a community level, the migration becomes deep in the people's actions, and relevant values with migration become a part of community value. For young men and women, the migration is good, and those who try to enhance their abilities through the migrant movement are thought as a person who has a lot of ambition (Reichert, 1982).

\subsection{Proposed research model}

Pursuant to theory models for migration and last researches, the analytic frame for this topic is concentrated in migrant pull factors as follows:

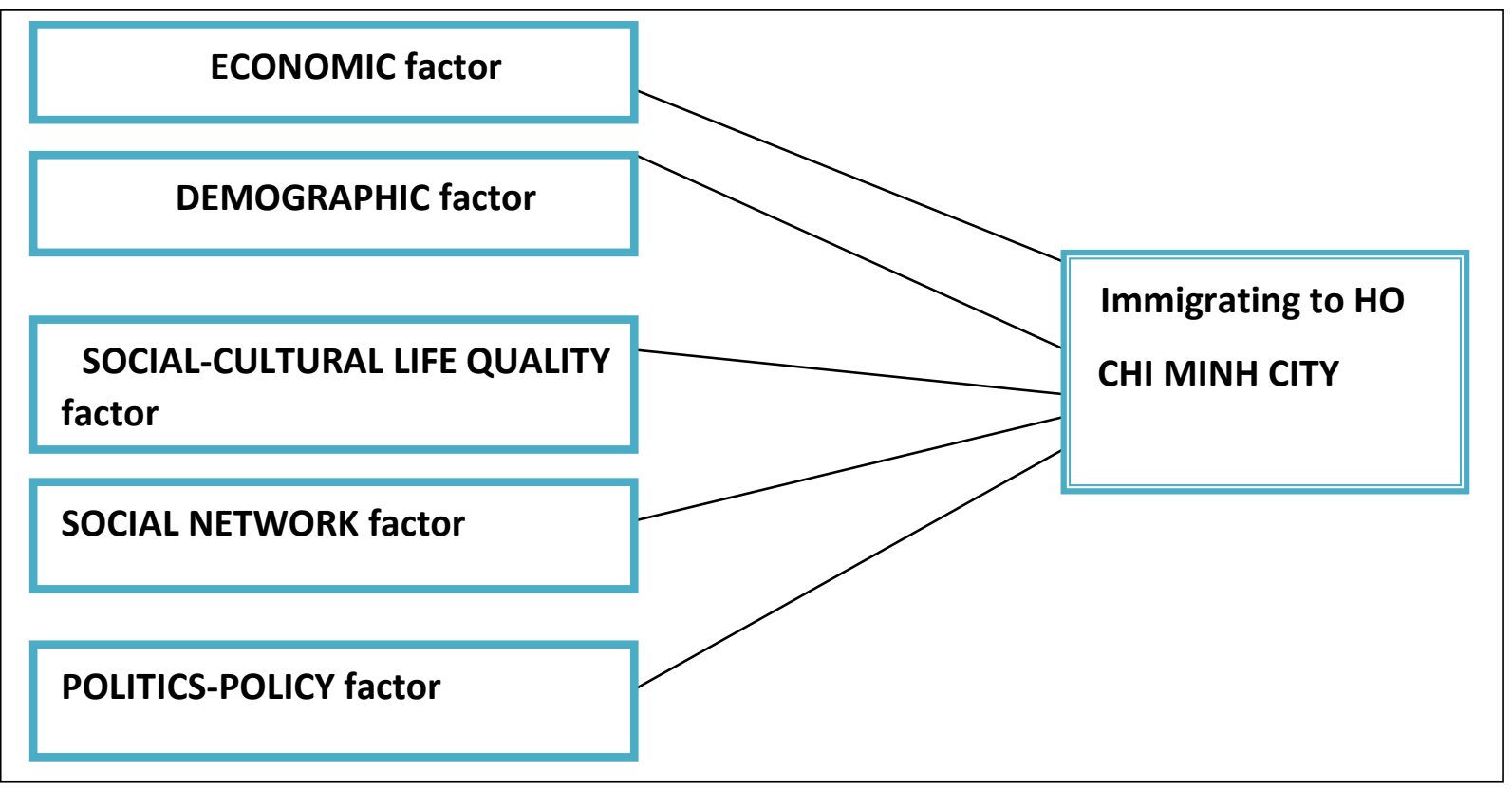

Figure 1. Model of factors impacts to HCMC immigration 


\section{Table 1}

Factors of affecting on migration into Ho Chi Minh City

\begin{tabular}{|c|c|}
\hline \multicolumn{2}{|l|}{ Group of Economic factors } \\
\hline Income & (Lewis, 1954) \\
\hline Jobs & (Harris \& Todaro, 1970; Olajide \& Udoh, 2012) \\
\hline Capital market & $\begin{array}{l}\text { (Katz \& Stark, 1986; Lauby \& Stark, 1988; } \\
\text { Stark, 1984; Stark, 1991; Stark \& Levhari, 1982; } \\
\text { Taylor, 1986) }\end{array}$ \\
\hline Future Market & $\begin{array}{l}\text { (Katz \& Stark, 1986; Lauby \& Stark, 1988; } \\
\text { Stark, 1984; Stark, 1991; Stark \& Levhari, 1982; } \\
\text { Taylor, 1986) }\end{array}$ \\
\hline Agricultural insurance market & $\begin{array}{l}\text { (Katz \& Stark, 1986; Lauby \& Stark, 1988; } \\
\text { Stark, 1984; Stark, 1991; Stark \& Levhari, 1982; } \\
\text { Taylor, 1986) }\end{array}$ \\
\hline Unemployment insurance & $\begin{array}{l}\quad \text { (Katz \& Stark, 1986; Lauby \& Stark, 1988; } \\
\text { Stark, 1984; Stark, 1991; Stark \& Levhari, 1982; } \\
\text { Taylor, 1986) }\end{array}$ \\
\hline \multicolumn{2}{|l|}{ Group of Demographic factors } \\
\hline Rapid increase in rural population & (Plymas, 1999) \\
\hline Education level of migrants & (Mowat, 1977; Plymas, 1999) \\
\hline $\begin{array}{l}\text { Marriage and opportunities for } \\
\text { marriage }\end{array}$ & $\begin{array}{l}\text { (Lee, 1966; Prutipinyo, 2003; Suthum } \\
\text { Nanthamongkongchai, 1999; Wanna Kobarun, } \\
\text { 1999) }\end{array}$ \\
\hline Living near relatives & Lee (1966) \\
\hline Number of dependents & (Ratchanee Kunopakarn, 1999) \\
\hline Size of family & $\begin{array}{l}\text { (de Jong \& Ferguson-Hessler, 1996; Vorakitwat, } \\
\text { 2001) }\end{array}$ \\
\hline \multicolumn{2}{|c|}{ Group of Social - cultural - life quality factors } \\
\hline Education & (Lee, 1966; Q. Nguyen, 1996) \\
\hline Health services & (Lee, 1966; T. Q. Nguyen, 2009) \\
\hline Personal aspiration & (Kainth, 2010) \\
\hline A better living condition & Lee (1966) \\
\hline Entertainment conditions & Lee (1966) \\
\hline Allocate human capital by region & $\begin{array}{l}\text { (Greenwood, 1981, 1985; Greenwood, Hunt, \& } \\
\text { McDowell, 1986; Myrdal, 1957) }\end{array}$ \\
\hline
\end{tabular}




\begin{tabular}{|l|l|}
\hline \multicolumn{2}{|l|}{ Group of Social network factors } \\
\hline Cost reduction & (Massey, 1990; D. V. Nguyen, 2005) \\
\hline Risk management in life & (Gurak \& Caces, 1992; Massey \& Espafia, 1987) \\
\hline Friends and fellow countryman & (Kainth, 2010) \\
\hline Family & (Kainth, 2010) \\
\hline Politics factor group & Lee (1966) \\
\hline Security of living environment & Decree 56/2010 / ND-CP dated 24-5-2010 \\
\hline $\begin{array}{l}\text { Ho Chi Minh City household } \\
\text { registration }\end{array}$ & Le Van Thanh, 2008 \\
\hline Poverty reduction policy & Le Van Thanh, 2008 \\
\hline $\begin{array}{l}\text { Caring and dedicated support of } \\
\text { local authorities }\end{array}$ &
\end{tabular}

Source: The researcher's data analysis

\section{Research method}

\subsection{Set up the measuring scale and design the questionnaire}

Studying factors impacting to immigrate to the city, and using the scale Likert that are 5 levels as follows: level 1: very disagreed; level 2: disagreed; level 3: normal; level 4: agreed; level 5: very agreed. Questions in relation to migrant influenced factors concentrated on 06 parts: Part 1 consists of the common information on interviewed objects as sex, age, education level, marital situation; Part 2 includes questions in relation to the economic factor group; Part 3 is a list of questions in relation to the demographic factor group; Part 4 relates to the socialcultural factor group - life quality; Part 5 relates to the social network factor group; and Part 6 relates to the state politics-policy factor group. Following the questionnaire is tested on 20 people prior to fully conducted to get official deployment and data collection.

\subsection{Method for choosing sample and sample scale}

Participants are immigrants to HCMC including living and working in this place with the age 18 to 59 and HCMC stayed period from more than 5 years (Following the research point of 1999, 2009 Population and Housing Census and the 2014 Intercensal Population and Housing Census Survey, focusing mainly on migration with a period of 5 years) to answer questions directly. When conducting an investigation, there are only 277 attained samples and 23 unattained samples, occupied over $92 \%$ of purposed samples. Data were collected at 3 advantageous areas namely District 7, Tan Binh District and Binh Thanh District since those have a higher rate of immigrants and emigrant groups. 


\section{Analysis of researching result}

\subsection{Statistics analysis of quantitative variables}

Table 2

Statistic for describing quantitative variables

\begin{tabular}{|c|c|c|c|c|c|}
\hline Name of variables & Median & $\begin{array}{l}\text { Minimum } \\
\text { value }\end{array}$ & $\begin{array}{l}\text { Maximum } \\
\text { value }\end{array}$ & $\begin{array}{c}\text { Average } \\
\text { value }\end{array}$ & $\begin{array}{l}\text { Standard } \\
\text { deviation }\end{array}$ \\
\hline \multicolumn{6}{|l|}{ Group of Economic factors } \\
\hline $\begin{array}{l}\text { KT1 (HCMC provides better } \\
\text { working chances) }\end{array}$ & 4 & 1 & 5 & 4.03 & .868 \\
\hline $\begin{array}{l}\text { KT2 (migrating to HCMC } \\
\text { to success/promotion) }\end{array}$ & 4 & 1 & 5 & 3.68 & .937 \\
\hline $\begin{array}{l}\text { KT3 (diversified } \\
\text { working opportunities } \\
\text { in HCMC) }\end{array}$ & 4 & 1 & 5 & 4.11 & .815 \\
\hline $\begin{array}{l}\text { KT4 (more saving to } \\
\text { contribute for the family } \\
\text { economics when working in } \\
\text { HCMC) }\end{array}$ & 4 & 1 & 5 & 2.96 & 1.001 \\
\hline $\begin{array}{l}\text { KT5 (HCMC makes } \\
\text { opportunities to earn } \\
\text { money easily in order to } \\
\text { support the family } \\
\text { economics) }\end{array}$ & 4 & 1 & 5 & 3.70 & .889 \\
\hline $\begin{array}{l}\text { KT6 (HCMC makes the } \\
\text { working opportunities with } \\
\text { more stable incomes to send } \\
\text { money to home) }\end{array}$ & 4 & 1 & 5 & 3.60 & .957 \\
\hline \multicolumn{6}{|l|}{ Group of Demographic factors } \\
\hline $\begin{array}{l}\text { NH1 (After completing the } \\
\text { vocational/studying education } \\
\text { in HCMC, I decided to stay at } \\
\text { HCMC and looking for better } \\
\text { job opportunities) }\end{array}$ & 4 & 1 & 5 & 3.69 & .984 \\
\hline $\begin{array}{l}\mathrm{NH} 2 \text { (After completing the } \\
\text { vocational/studying education } \\
\text { in the countryside, I decided to } \\
\text { move into HCMC in order to } \\
\text { look for better job } \\
\text { opportunities) }\end{array}$ & 4 & 1 & 5 & 3.34 & .940 \\
\hline
\end{tabular}




\begin{tabular}{|c|c|c|c|c|c|}
\hline Name of variables & Median & $\begin{array}{c}\text { Minimum } \\
\text { value }\end{array}$ & $\begin{array}{l}\text { Maximum } \\
\text { value }\end{array}$ & $\begin{array}{l}\text { Average } \\
\text { value }\end{array}$ & $\begin{array}{l}\text { Standard } \\
\text { deviation }\end{array}$ \\
\hline $\begin{array}{l}\mathrm{NH} 3 \text { (to get married to a } \\
\text { husband/wife in HCMC, then I } \\
\text { decide to migrate to the city) }\end{array}$ & 4 & 1 & 5 & 3.09 & 1.167 \\
\hline $\begin{array}{l}\text { NH4 (the migrant purpose to } \\
\text { HCMC is unified with their } \\
\text { family or lived together with } \\
\text { their relatives) }\end{array}$ & 4 & 1 & 5 & 2.88 & 1.149 \\
\hline $\begin{array}{l}\text { NH5 (because the family has } \\
\text { a lot of dependants, they } \\
\text { migrate to HCMC to work } \\
\text { and send money back home) }\end{array}$ & 4 & 1 & 5 & 2.74 & 1.206 \\
\hline $\begin{array}{l}\text { NH6 (because of the family } \\
\text { with crowded siblings, they } \\
\text { migrate to HCMC in order to } \\
\text { easily work and increase } \\
\text { family incomes) }\end{array}$ & 4 & 1 & 5 & 2.70 & 1.173 \\
\hline \multicolumn{6}{|l|}{$\begin{array}{l}\text { Group of Social - cultural - life } \\
\text { quality factors }\end{array}$} \\
\hline $\begin{array}{l}\text { VH1 (migrating to urban in } \\
\text { order to access better } \\
\text { education) }\end{array}$ & 4 & 1 & 5 & 3.91 & .894 \\
\hline $\begin{array}{l}\mathrm{VH} 2 \text { (migrating to urban } \\
\text { in order to access better } \\
\text { health services and needs) }\end{array}$ & 4 & 1 & 5 & 3.62 & .942 \\
\hline $\begin{array}{l}\text { VH3 (migrating to urban } \\
\text { in order to carry out } \\
\text { individual desire) }\end{array}$ & 4 & 1 & 5 & 3.60 & .930 \\
\hline $\begin{array}{l}\text { VH4 (migrating to urban in } \\
\text { order to expect the freedom } \\
\text { life) }\end{array}$ & 4 & 1 & 5 & 2.99 & 1.018 \\
\hline $\begin{array}{l}\text { VH5 (migrating to urban } \\
\text { in order to have better life } \\
\text { condition) }\end{array}$ & 4 & 1 & 5 & 3.51 & .995 \\
\hline $\begin{array}{l}\text { VH6 (migrating to urban in } \\
\text { order for a better } \\
\text { entertainment condition) }\end{array}$ & 4 & 1 & 5 & 3.34 & 1.057 \\
\hline
\end{tabular}




\begin{tabular}{|c|c|c|c|c|c|}
\hline Name of variables & Median & $\begin{array}{c}\text { Minimum } \\
\text { value }\end{array}$ & $\begin{array}{l}\text { Maximum } \\
\text { value }\end{array}$ & $\begin{array}{c}\text { Average } \\
\text { value }\end{array}$ & $\begin{array}{l}\text { Standard } \\
\text { deviation }\end{array}$ \\
\hline \multicolumn{6}{|l|}{ Group of Social network factors } \\
\hline $\begin{array}{l}\text { MXH1 (migrating to } \\
\text { HCMC according to } \\
\text { everybody's migrant } \\
\text { movement) }\end{array}$ & 4 & 1 & 5 & 2.51 & 1.134 \\
\hline $\begin{array}{l}\text { MXH2 (migrating to } \\
\text { HCMC due to friends' } \\
\text { embroilment) }\end{array}$ & 4 & 1 & 5 & 2.39 & 1.087 \\
\hline $\begin{array}{ll}\text { MXH3 (migrating to } \\
\text { HCMC due } & \text { to } \\
\text { countryman's } & \\
\text { embroilment) } & \end{array}$ & 4 & 1 & 5 & 2.40 & 1.107 \\
\hline $\begin{array}{l}\text { MXH4 (migrating to HCMC } \\
\text { due to relatives' convincing } \\
\text { and encouragement) }\end{array}$ & 4 & 1 & 5 & 2.83 & 1.134 \\
\hline \multicolumn{6}{|l|}{ Politics factor group } \\
\hline $\begin{array}{l}\text { CT1 (migrating to HCMC } \\
\text { due to secure life } \\
\text { environment) }\end{array}$ & 4 & 1 & 5 & 2.71 & 1.065 \\
\hline $\begin{array}{l}\text { CT2 (migrating to HCMC } \\
\text { due to the advantageous } \\
\text { policy of entering) }\end{array}$ & 4 & 1 & 5 & 2.57 & 1.093 \\
\hline $\begin{array}{l}\text { CT3 (migrating to HCMC } \\
\text { due to the policy for poverty- } \\
\text { alleviation program and } \\
\text { capital lending) }\end{array}$ & 4 & 1 & 5 & 2.47 & .961 \\
\hline $\begin{array}{l}\text { CT4 (migrating to HCMC due } \\
\text { to consideration of local public } \\
\text { services and authorities } \\
\text { especially examining KT3 and } \\
\text { other administrative } \\
\text { procedures) }\end{array}$ & 4 & 1 & 5 & 2.40 & .990 \\
\hline $\begin{array}{l}\text { CT5 (migrating to HCMC } \\
\text { due to the local } \\
\text { government's material and } \\
\text { spiritual support) }\end{array}$ & 4 & 1 & 5 & 2.35 & .946 \\
\hline
\end{tabular}




\begin{tabular}{|l|c|c|c|c|c|}
\hline \multicolumn{1}{|c|}{ Name of variables } & Median & $\begin{array}{c}\text { Minimum } \\
\text { value }\end{array}$ & $\begin{array}{c}\text { Maximum } \\
\text { value }\end{array}$ & $\begin{array}{c}\text { Average } \\
\text { value }\end{array}$ & $\begin{array}{c}\text { Standard } \\
\text { deviation }\end{array}$ \\
\hline $\begin{array}{l}\text { CT6 (migrating to HCMC } \\
\text { due to advantageous } \\
\text { administrative procedures) }\end{array}$ & 4 & 1 & 5 & 2.59 & 1.075 \\
\hline
\end{tabular}

Source: Data analysis result of the research

Group of economic factors: the average value of the lowest observed variable is from 2.96 to 4.11, including the highest valuation is KT3 variable (more diversified job opportunities than HCMC) and KT1 (HCMC supplies better job chances) with the average value in turn as 4.11 and 4.03, following KT5 (HCMC creates easier chances for earning money to support the family economics), KT2 (migrating to HCMC in order to succeed /promote), KT6 (HCMC creates the working chances with more stable incomes to send money to home) with the average value is in turn as 3.70, 3.68, 3.60. The lowest variable is KT4 (working in HCMC shall save more money to contribute the family economics) with an average value of 2.96 .

Group of demographic factors: the highest appreciated variables are NH1 (after completing vocational/studying education in HCMC, I decided to stay there to look for the job chances), NH2 (after completing vocational/studying education in countryside, I decided to migrate to HCMC looking for better job chances) the average value is in turn as 3.69, 3.64. Variables are average appreciated NH3 (getting married to husband/wife in HCMC, I carried out to move to the city), NH4 (moving to HCMC with the family unified purpose or living together relatives) the average value is in turn as 3.09, 2.88, and variables are the lowest average value NH5 (the family has a lot of dependants, they migrate to HCMC to work and send money back to home), NH6 (the family with crowded siblings, they migrate to HCMC in order to easily work and increase family incomes) within turn the average value 2.74, 2.70 .

Group of social - cultural - life quality factors: the highest average value is the VH1 variable (migrating to urban in order to access better education) with the value 3.69. The average variables are $\mathrm{VH} 2$ (migrating to urban in order to access better health services and needs) with the value 3.62, VH3 (migrating to urban in order to carry out individual desire) with the value 3.60, and VH5 (migrating to urban in order to better life condition) with the value 3.51. The lowest variables are VH6 (migrating to urban in order to be better entertainment conditions) with the value 3.34, and VH4 (migrating to urban in order to expect the freedom of life) with the lowest value of 2.99 .

Group of social network factors: The highest appreciated variable is MXH4 (migrating to HCMC due to relatives' convincement and encouragement) with the average value 2.83, following MXH1 (migrating to HCMC according to everybody's migrant movement) with the value 2.51. The lowest variables are $\mathrm{MXH3}$ (migrating to HCMC due to countryman's embroilment), MXH2 (migrating to HCMC due to friends' embroilment) with the value in turn as 2.40 and 2.39 .

Politics factor group: CT1 (migrating to HCMC due to secure life environment), CT6 (migrating to HCMC due to advantage administrative procedures), CT2 (migrating to HCMC due to the advantage policy when entering) are appreciated highest variables with the value in 
turn as $2.71,2.59,2.57$. The average variable in this group is CT3 (migrating to HCMC due to the policy for poverty-alleviation program and capital lending) with the value 2.47 , CT4 (migrating to HCMC due to consideration of local public services and authorities especially examining KT3 and other administrative procedures) with the value 2.40, and the lowest variable is CT5 (migrating to HCMC due to the local government's help for material and spiritual) with the value 2.35 .

\subsection{Test Cronbach's Alpha for measuring scale}

Cronbach's Alpha Coefficient is used to appreciate the convergence of observed variables measuring a certain factor in the researching model and to eliminate unsuitable variables. Audited result for the fail-safety of measuring scale in table 2 as follows:

\section{Table 3}

Test Cronbach's Alpha of measuring scale

\begin{tabular}{|l|c|c|}
\hline \multicolumn{1}{|c|}{ Name of measuring scale } & $\begin{array}{c}\text { Observed variables in each } \\
\text { measuring scale }\end{array}$ & $\begin{array}{c}\text { Cronbach's } \\
\text { Alpha } \\
\text { Coefficient }\end{array}$ \\
\hline Scale 1: Economics factor group & KT1, KT2, KT3, KT4, KT5, & Alpha: 0.807 \\
\hline Scale 2: Demographic factor group & $\begin{array}{c}\text { NH1, NH2, NH3, NH4, NH5, } \\
\text { NH6 }\end{array}$ & Alpha :0.736 \\
\hline $\begin{array}{l}\text { Scale 3: Social-cultural-life quality } \\
\text { factor }\end{array}$ & VH1, VH2, VH3, VH4, VH5, & Alpha: 0.785 \\
\hline Scale 4: Social network & VH6 & \\
\hline Scale 5: Politics - policy & CT1, CT2, CT3, CT4, CT5, CT6 & Alpha : 0.905 \\
\hline
\end{tabular}

Source: Data analysis result of the research

\subsection{Exploratory factor analysis (EFA-Exploratory Factor Analysis)}

\section{Table 4}

Statistics for measuring scale and observed variables in EFA

\begin{tabular}{|l|c|}
\hline \multicolumn{1}{|c|}{ Measuring scale } & $\begin{array}{c}\text { Observed variables } \\
\text { number }\end{array}$ \\
\hline 1. Economic factor group & 6 \\
2. Demographic factor group & 6 \\
3. Society - culture - life quality factor group & 6 \\
4. Social network factor group & 4 \\
5. Politics-policy factor group & 6 \\
\hline Total & 28 \\
\hline
\end{tabular}

Source: Data analysis result of the research 
Choosing the factor loading coefficient is 0.55 with the numeric value $(0.5<\mathrm{KMO}<1)$ Bartlett's test on interrelating between observed variables is statistic meaning level with Sig. < 0.05, extract variance $>50 \%$ (Hair, Anderson, Tatham, \& Black, 1998), method of principal component extract and Varimax turn. After analyzing the exploratory factor, the results are as follows: EFA for the second time stated that when eliminating an unmet variable in first factor analysis time (KT4 variable) shall be Coefficient $\mathrm{KMO}=0.762$ (satisfied condition $0.5 \leq \mathrm{KMO}$ $\leq 1$ ) with meaning level Sig $=0.00$ in Bartlett's test (satisfied condition Sig $<0.5$ ). Results of EFA stated 6 factors extracted in Eigenvalue are 1.230 and variance $70.618 \%$ (satisfied condition > 50\%). It is stated the above 6 factors explained $70.618 \%$ data and the factor loading coefficient is larger 0.55 , so it is suitable for the following analytic table.

\section{Table 5}

KMO and Bartlett's Test (EFA for the second time)

\begin{tabular}{|c|c|c|}
\hline \multicolumn{2}{|c|}{ KMO and Bartlett's Test } \\
\hline \multicolumn{2}{|c|}{ Kaiser-Meyer-Olkin Measure of Sampling Adequacy. } & .762 \\
\hline $\begin{array}{c}\text { Bartlett's Test of } \\
\text { Sphericity }\end{array}$ & Approx. Chi-Square & 4826.834 \\
\cline { 2 - 3 } & $\mathrm{df}$ & 300 \\
\cline { 2 - 3 } & Sig. & .000 \\
\hline
\end{tabular}

Source: Data analysis result of the research

\section{Table 6}

Extracted variance (EFA for second time)

\begin{tabular}{|c|c|c|c|c|c|c|}
\hline \multirow{2}{*}{ Component } & \multicolumn{3}{|c|}{$\begin{array}{c}\text { Extraction Sums of Squared } \\
\text { Loadings }\end{array}$} & \multicolumn{3}{c|}{$\begin{array}{c}\text { Rotation Sums of Squared } \\
\text { Loadings }\end{array}$} \\
\cline { 2 - 7 } & Total & $\begin{array}{c}\text { \% of } \\
\text { Variance }\end{array}$ & $\begin{array}{c}\text { Cumulative } \\
\text { \% }\end{array}$ & Total & $\begin{array}{c}\text { \% of } \\
\text { Variance }\end{array}$ & $\begin{array}{c}\text { Cumulative } \\
\%\end{array}$ \\
\hline 1 & 6.993 & 27.974 & 27.974 & 4.579 & 18.315 & 18.315 \\
\hline 2 & 4.267 & 17.067 & 45.041 & 3.441 & 13.763 & 32.078 \\
\hline 3 & 2.263 & 9.054 & 54.094 & 2.590 & 10.360 & 42.438 \\
\hline 4 & 1.553 & 6.212 & 60.307 & 2.579 & 10.317 & 52.755 \\
\hline 5 & 1.348 & 5.392 & 65.698 & 2.278 & 9.111 & 61.866 \\
\hline 6 & 1.230 & 4.920 & 70.618 & 2.188 & 8.753 & 70.618 \\
\hline Extraction Method: Principal Component Analysis. & & & \\
\hline
\end{tabular}

Source: Data analysis result of the research 


\section{Table 7}

Results of second time rotated factor matrix

\begin{tabular}{|c|c|c|c|c|c|c|}
\hline \multicolumn{7}{|c|}{ Rotated Component Matrix ${ }^{a}$} \\
\hline & \multicolumn{3}{|c|}{ Component } & & & \\
\hline & 1 & 2 & 3 & 4 & 5 & 6 \\
\hline CT4 & .907 & & & & & \\
\hline CT3 & .893 & & & & & \\
\hline CT5 & .863 & & & & & \\
\hline CT6 & .754 & & & & & \\
\hline CT2 & .749 & & & & & \\
\hline CT1 & .587 & & & & & \\
\hline MXH2 & & .822 & & & & \\
\hline MXH3 & & .817 & & & & \\
\hline NH5 & & .734 & & & & \\
\hline MXH1 & & .726 & & & & \\
\hline NH6 & & .683 & & & & \\
\hline VH6 & & & .767 & & & \\
\hline VH5 & & & .710 & & & \\
\hline VH4 & & & .698 & & & \\
\hline VH3 & & & .626 & & & \\
\hline KT3 & & & & .846 & & \\
\hline KT1 & & & & .802 & & \\
\hline KT2 & & & & .633 & & \\
\hline KT6 & & & & & .773 & \\
\hline $\mathrm{NH} 2$ & & & & & .700 & \\
\hline KT5 & & & & & .656 & \\
\hline NH1 & & & & & .604 & \\
\hline $\mathrm{NH} 3$ & & & & & & .795 \\
\hline $\mathrm{NH} 4$ & & & & & & .705 \\
\hline MXH4 & & & & & & .633 \\
\hline
\end{tabular}




\begin{tabular}{|l|l|}
\hline \multicolumn{2}{|c|}{ Rotated Component Matrix $^{\mathbf{a}}$} \\
\hline & \multicolumn{1}{|c|}{ Component } \\
\hline $\begin{array}{l}\text { Extraction Method: Principal Component Analysis. Rotation Method: Varimax } \\
\text { with Kaiser Normalization. }\end{array}$ & \\
\hline
\end{tabular}

Source: Data analysis result of the research

\section{Explanation on factors after EFA}

Factor F1_HCMC politics and policy consists of CT1 (migrating to HCMC due to secure life environment), CT2 (migrating to HCMC due to the advantageous policy of entering), CT3 (migrating to HCMC due to the policy for poverty-alleviation program and capital lending), CT4 (migrating to HCMC due to consideration of local public services and authorities especially examining KT3 and other administrative procedures), CT5 (migrating to HCMC due to the local government's help for material and spiritual), CT6 (migrating to HCMC due to advantageous administrative procedures). Variables depending on this factor related to politics and policy factors of HCMC authority.

Factor F2_family situation and friends and countryman's embroilment consists of 5 variables, including 3 observed variables under social network factor namelyMXH1 (migrating to HCMC according to everybody's migrant movement), $\mathrm{MXH} 2$ (migrating to HCMC due to friends' embroilment), and MXH3 (migrating to HCMC due to countryman's embroilment) and two variables under the demographic factor group including NH5 (because the family has a lot of dependants, they migrate to HCMC to work and send money to home); NH6 (because of the family with crowded sibling, they migrate to HCMC easily in order to work and increase in family incomes). The variables related to migrating to HCMC under the movement of previous migrants, friends and countryman's embroilment, furthermore emigrants who are ready for migrating such as they leave out due to their family with the crowded sibling or dependants. If it is analyzed clearly, the above 5 variables are the entire supplementary and mutual advantage resonance in the decision of the city migration. Three variables with the pretty high factor loading coefficient are MXH2, MXH3, and NH5 in turn as 0.822, 0.817 and 0.734.

Factor F3_better life quality needs and the individual ambition's implement consists of 4 variables depending on Society - culture - life quality factor group, including VH3 (migrating to urban in order to carry out individual desire); VH4 (migrating to urban in order to expect the freedom life); VH5 (migrating to urban in order to be better life condition); VH6 (migrating to urban in order to better entertainment condition). These variables related to individual needs such as needs for better entertainment and life condition, freedom life desire. It is explained by described and statistics analysis on the age of interviewers hereby in around 18-25 years, occupied $41.9 \%$. Two variables with a pretty high factor loading coefficient are in turn as 0.767 and 0.710 for variable VH6 and VH5.

Factor F4_job opportunities and professional development condition consist of 3 observed variables in relation to the economic factor group, including KT1 (HCMC supplies better working chances); KT2 (migrating to HCMC to success/promote); KT3 (diversiform 
working opportunities in HCMC). These variables related to job issues and promoted opportunities in the profession. There are two variables with the high factor loading coefficient in turn as 0.846 and 0.802 correlative with variables KT3 and KT1. This is a suitable reality because almost all people in the labor age or with education and high skill always trend to migrate to HCMC looking for jobs or other job change chances. To do that thing, as stated, $\mathrm{HCMC}$ is the economic center and here supplying diversified lines. On the occasion of the late year Tet, we saw clearly many people stream moving to the countryside for Tet, the city becomes clear, little vehicles. And then, people stream to return to HCMC and continuing their work after the holiday.

Factor F5_ working demand with stable incomes consists of 4 observed variables, including two variables under the economic factor group: KT5 (HCMC makes opportunities to earn money easily in order to support the family economics); KT6 (HCMC makes the working opportunities with more stable incomes to send money to home), these variables related to the economic factor, emigrants hope that HCMC environment is easier looking for jobs and stable because there are to sign the labor contract when working and protected by the labor union; or in worse situation, labours can find other jobs easily in the shortest period if they quit a certain job. The city is more advantageous than the countryside. Two variables depend on the demographic factor including NH1 (After completing the vocational/ studying education in HCMC, I decided to stay at HCMC and looking for better job opportunities); NH2 (After completing the vocational/studying education in countryside, I decided to move into HCMC in order to look for better job opportunities). Two variables related to the demographic factor, labours after finishing their education or vocation, in spite of learning in HCMC or in other areas, finally they make a decision move to HCMC working. In this factor two variables with relatively high factor loading coefficient in turn as 0.773 and 0.700 for variable KT6 and NH2.

Factor F6_ marriage and living next to relatives consists of 3 observed variables, including two variables related to the demographic factor: $\mathrm{NH} 3$ (getting married to husband/wife in HCMC, I carried out to move to the city), NH4 (moving to HCMC with the family unified purpose or living together with relatives). Two of these variables related to the marriage and unified family issues_those who living outer of HCMC get married to people in HCMC, their family shall be settled in HCMC for many reasons such as advantageous working conditions, children's educational condition in future. Living next to relatives is also a factor for migrating to HCMC living and working, this is an indispensable and common need in present. A variable related to the social network factor MXH4 (migrating to HCMC due to relatives' convincement and encouragement). This factor happened by relatives' convincing and encouragement in family, it is explained that passing the social network, relatives chose a member of family (with young, skill and strong labor) to migrate to the city; or the family had relatives or sibling previously migrated or lived in HCMC, they call and encourage the rest of family members to accompany them. 


\section{Conclusion and policy suggestion}

\subsection{Conclusion}

The immigration to HCMC is very diversified with long-form in short time regularly going and getting back in order to an increase in casual incomes, to send money to family, to change the environment, to access to better and educational health services, to get married, transfer business or demand for living near the relatives. However, each household and individual adaptation when living and working in the city is the most common point among the types of migration. Maybe stating a migrant decision to HCMC is an exchange in one's life, thus the final goal of the research is to find out the main cause affecting the emigrants' decisions for immigrating to HCMC. The last analyzed result stated that there are 6 main factor groups influencing the migrant decision to the city, particularly: F1 (HCMC politics and policy factor), F2 (family situation and friends and countryman's embroilment factors), F3 (factors of better life quality needs and the individual aspirations), F4 (job opportunities and professional development condition), F5 (working demand with stable incomes), F6 (marriage and living next to relatives).

\subsection{Policy suggestions}

The city must take consideration of the emigrants being an urban component and prepare separate policies for them so that they keep their minds on their work and contribute to the entire city's development in general.

For HCMC politics and policy factor $(\mathrm{F1})$ : the procedure issue in relation to the KT3, provisional residential registration and entering the household are the first consideration when people migrate to the city because these procedures directly related to application record and the labor's life. The city government must set up locations to supply information for migrant labors on their right, and administrative procedures for the household registration as well as simplifying procedures for immigration objects. In addition to the local authorities' consideration, public services and urban groups are also people's expectations. The local authorities must ensure suitable, safe and healthy housing supplies with reasonable costs for workers.

For family situation and friends and countryman's embroilment factors (F2): the social network is developed very popularly in the current living rate because of telephone and internet services' development being very closely involved in people's lives all over Vietnam. Since then, passing the social network, friends and countryman's embroilment, emigrants are attracted to the city the most. And one of the factors pushing people to move is the family situation with many dependents. Preferential policy for medical services, health, reproduction and other supports for objects in the social supporting program are also very significant.

For factors of better life quality needs and the implementation of individual aspirations (F3): the city government suggestion must design, apportion budgets and supply social services under the manner in which immigrant participants can access these services easily. As for accommodations and individual activities must also be under the safe condition, suitable hygiene and more improved life condition, especially for emigrants with low incomes, 
workers of industrial zones the freshwater, electricity, and hygiene accessing factors must be prioritized.

For the economic factor (F4): information on vocational training and supporting services in order to avoid the merchandized situation or sexy abuse are also very essential for immigrants. The provided information must be suitable for each age and sensitive gender.

For the factor of working demand with stable incomes (F5): the city government must change the suitable economics policy to attract and use the reasonable migrant labor streams and have stable working conditions. It is a proper working policy for each educational level of immigrants, the social and health insurance's regime clearly and free of legal information channel from authority levels for protecting the use of labor immigrants and supporting the job in case of jobless immigrants.

For factors of marriage and living next to relatives (F6): the city must improve and develop the infrastructure network, advantageous land traffic to restrict the traffic jam and the environmental pollution. It is to advance the community's knowledge on the environment's importance for life's health and quality. HCMC should also exploit information and data of the environmental pollution on means of communication to enhance people's awareness in urban living environment protection. It is to promote the public means' development and a friendly environment.

\subsection{Practical meaning and limitations of the research}

Using the EFA method has identified key factors affecting migrants in choosing Ho Chi Minh City to immigrate so that the results of the research contribute to the city's government and help them to have an overall view in designing and implementing solutions that benefit immigrants. However, this study also has its limitations on research patterns, as well as providing inaccuracies for other forms of migration. Furthermore, encouraging quantitative research methods should be implemented to more accurately determine the impact factors as well as the specified impact of each factor.

\section{References}

Central Population Housing Census Steering Committee. (2010). The 1999 Vietnam Population and Housing Cencus. Hanoi, Vietnam: Central Population and Housing Census Steering Committee.

Central Population Housing Census Steering Committee. (2010). The 2009 Vietnam Population and Housing Cencus. Hanoi, Vietnam: Central Population and Housing Census Steering Committee.

de Jong, T., \& Ferguson-Hessler, M. G. M. (1996). Types and qualities of knowledge. Educational Psychologist, 31(2), 105-113.

General Statistics Office - United Nations Population Fund. (2004). Migration and health. Retrieved October 20, 2018, from http://vietnam.unfpa.org 
General Statistics Office - United Nations Population Fund. (2011). Migration and urbanization in Vietnam - Reality, trend and differences. Retrieved October 18, 2018, from Ministry of Planning and Investment General Statistics Office website: https://vietnam.unfpa.org/sites/default/files/pub-pdf/7_Monograph-MigrationUrbanization.pdf

General Statistics Office - United Nations Population Fund. (2014). The 2014 Viet Nam intercensal population and housing survey fertility in Vietnam: Differentials, trends, and determinants. Hanoi, Vietnam: Vietnam News Agency Publishing House.

Greenwood, M. J. (1981). Migration and economic growth in the United States. Cambridge, MA: Academic Press.

Greenwood, M. J. (1985). Human migration: Theory, models, and empirical evidence. Journal of Regional Science, 25(4), 521-544. doi:10.1111/j.1467-9787.1985.tb00321.x

Greenwood, M. J., Hunt, G. L., \& McDowell, J. M. (1986). Migration and employment change: Empirical evidence on the spatial and temporal dimensions of the linkage. Journal of Regional Science, 26(2), 223-234. doi:10.1111/j.1467-9787.1986.tb00818.x

GSO - United Nations Population Fund. (2005). Migrant investigation 2004 - Key outcomes. Hanoi, Vietnam: Statistic Publisher, General Statistics Office.

Gurak, D., \& Caces, F. (1992). Migration networks and the shaping of migration systems. In M. M. Kritz (Ed.), International migrations systems: A global approach (pp. 150-176). Oxford, UK: Clarendon Press.

Hair, J.-F., Anderson, R. E., Tatham, R. L., \& Black, W. C. (1998). Multivariate data analysis with readings (5th ed.). Upper Saddle River, NJ: Prentice Hall.

Harris, J. R., \& Todaro, M. P. (1970). Migration, unemployment, and development: A twosector analysis. American Economic Review, 60(1), 126-142.

Kainth, G. S. (2010). Push and pull factors of migration: A case of Brick Kiln industry of Punjab State (Unpublished doctoral dissertation). University Library of Munich, Germany. Retrieved March, 13, 2019, from https://ideas.repec.org/p/pra/mprapa/30036.html

Katz, E., \& Stark, O. (1986). Labor migration and risk aversion in less developed countries. Journal of Labor Economics, 4(1), 134-149. doi:10.1086/298097

Lauby, J., \& Stark, O. (1988). Individual migration as a family strategy: Young women in the Philippines. Population studies-a Journal of Demography, 42, 157-173.

Lee, E. S. (1966). A theory of migration. Demography, 3(1), 47-57. Retrieved March 30, 2018, from http://www.jstor.org/stable/2060063

Lewis, W. A. (1954). Economic development with unlimited supplies of labour. The Manchester School, 22(2), 139-191. doi:10.1111/j.1467-9957.1954.tb00021.x 
Massey, D. (1990). Social structure, household strategies, and the cumulative causation of migration. Population Index, 56(1), 3-26. doi:10.2307/3644186

Massey, D. S., \& Espafia, F. G. (1987). The social process of international migration. Science, 237(4816), 733-738. doi:10.1126/science.237.4816.733

Ministry of Planning and Investment - General Statistics Office. (2001). Census of Population and housing 1999 Vietnam: Monograp on migration and Ha Noi urbanization. Hanoi, Vietnam: Statistics Publisher.

Mowat, S. (1977). Education and urban migration: A comparative analysis of case studies in Bangkok, Manila, and Jakarta. Bangkok: UNESCO Regional Office for Education in Asia.

Myrdal, G. (1957). Economic theory and underdeveloped regions. London, UK: University Paperbacks, Methuen.

Nguyen, D. V. (2005). Quản lý dư án xây dưng [Construction project management]. Dong Nai, Vietnam: Nhà xuất bản tổng hợp Đồng Nai.

Nguyen, Q. (1996). Freedom immigrants to Ho Chi Minh City: Researching the case of Go Vap District. Sociology, 3(55), 1-20.

Nguyen, T. Q. (2009). Push-Pull factor: Factors impacting the migartion in provinces and cities. Ho Chi Minh City, Vietnam: NXB Văn hóa - Thông tin.

Olajide, A., \& Udoh, G. (2012). Rural-urban migration: Migrants perceptions of problems and benefits in Oyo State Nigeria. Paper presented at International Conference on Humanities, Economics and Geography (ICHEG'2012) March 17-18, 2012 Bangkok.

Piore, M. J. (1979). Birds of passage: Migrant labor and industrial societies. Cambridge, UK: Cambridge University Press.

Plymas, K. (1999). Migration of young adults in rural Northeast Thailand: A study of gender differentials (Unpublished doctoral dissertation). Mahidal University, Thailand.

Population Fund. (2004). Vietnam migrant investigation 2004: Key outcomes, statistics Publisher 2005. Retrieved October 28, 2018, from http://www.gso.gov.vn

Prutipinyo, C. (2003). Thai elderly's working. Retrieved December 20, 2018, from http://elibrary.trf.or.th/project_content.asp?PJID=PDF4480090

Ranis, G., \& Fei, C. H. J. (1961). A theory of economic development. The American Economic Review, 51(4), 533-565. Retrieved from https://www.jstor.org/stable/1812785

Reichert, J. S. (1982). Social stratification in a Mexican sending community: The effect of migration to the United States. Social Problems, 29, 422-433. Retrieved March 15, 2018, from

https://www.researchgate.net/publication/307959122_Social_Stratification_in_a_Mexic an_Sending_Community_The_Effect_of_Migration_to_the_United_States 
Sjaastad, L. A. (1962). The costs and returns of human migration. Journal of Political Economy, 70(5), 80-93. doi:10.1007/978-1-349-15404-3_10

Stark, O. (1984). Migration decision making: A review article. Journal of Development Economics, 14, 251-259. doi:10.1016/0304-3878(84)90053-1

Stark, O. (1991). The migration of labor. Oxford, UK: Basil Blackwell.

Stark, O., \& Levhari, D. (1982). On migration and risk in LDCs. Economic Development and Cultural Change, 31(1), 191-196. doi:10.1086/451312

Suthashom, S. (2005). Factors influencing migration of rural labour in the Northeastern region of Thailand (Unpublished doctoral dissertation). National Institute of Development Administration, Thailand.

Suwanlee, P. (1974). Internal migration in Thailand 1860-1970 (Unpublished doctoral dissertation). University of Georgia, Georgia, USA.

Taylor, J. E. (1986). Differential migration, networks, information and risk. In O. Stark (Ed.), Research in human capital and development (Vol. 4, pp. 147-171). Greenwich, Conn.: JAI Press.

The Government. (2010). Decree No. 56/2010/ND-CP of May 24, 2010, amending and supplementing a number of Articles of the Government's Decree No. 107/2007/ND-CP of June 25, 2007, detailing and guiding a number of articles of the Law on Residence. Retrieved November 25, 2018, from https://vanbanphapluat.co/56-2010-nd-cp

Todaro, M. P. (1969). A model of labor migration and urban unemployment in less developed countries. The American Economic Review, 59(1), 138-148.

Todaro, M. P. (1976). Internal migration in developing countries: A review of theory, evidence, methodology and research priorities. Geneva, Switzerland: International Labour Office.

Todaro, M. P. (1980). Internal migration in developing countries: A survey. In A. E. Richard (Ed), Population and economic change in developing countries (pp. 361-401). Chicago, IL: University of Chicago Press.

Todaro, M. P. (1989). Economic development in the third world. New York, NY: Longman.

Todaro, M. P., \& Maruszko, L. (1987). Illegal migration and US immigration reform: A conceptual framework. Population and Development Review, 13(1), 101-114. doi: $10.2307 / 1972122$

Vorakit, K. (2001). Migration of rural northeastern people into Nakhon Pathom municipality after economic crisis (Master's thesis, Graduate School - Chulalongkorn University. Bangkok, Thailand). Retrieved November 25, 2018, from http://thaithesis.org/detail.php?id=1082544001368

Yap, L. (1977). The attraction of cities: A review of migration literature. Journal of Development Economics, 4(3), 239-264. doi:10.1016/0304-3878(77)90030-х 